\title{
Remarks on syllable structure and metrical structure in Biblical Hebrew
}

\author{
Geoffrey Khan \\ University of Cambridge, Cambridge, UK \\ gkıo1@cam.ac.uk
}

\begin{abstract}
In the Middle Ages Biblical Hebrew was transmitted in a variety of oral reading traditions, which became textualized in systems of vocalization signs. The two most important oral traditions were the Tiberian and the Babylonian, which were represented by different vocalization sign systems. These two oral traditions had their origins in ancient Palestine. Although closely related, they exhibit several differences. These include differences in syllable and metrical structure. This paper examines how the syllable and metrical structure of the two traditions reflected by the medieval vocalization sign systems should be reconstructed. The Tiberian tradition exhibits an 'onset typology' of syllabification, where word-internal /CCC/ clusters are syllabified /C.CC/ and word-initial clusters are syllabified within the onset /CC-/. The Babylonian tradition exhibits a right-to-left computation of syllables resulting in a 'coda typology,' whereby the second consonant of a word-internal sequence /CCC/ is syllabified as a coda, viz. /CC.C/, and word-initial clusters are syllabified C.C, with the first consonant extra-syllabic.
\end{abstract}

\section{Keywords}

Tiberian Hebrew - Babylonian Hebrew - syllable - syllabification - foot - vowel length - epenthesis - onset typology - coda typology 
In this paper I shall examine some features of the structure of syllables and metrical structure in the Tiberian and Babylonian reading traditions of Biblical Hebrew.

The Tiberian reading tradition is recorded by the Tiberian vocalization system, which is the system that appears in modern printed Bibles. This system of vocalization was developed by the Masoretes of Tiberias in the early Islamic period. It appears in a standardized form in medieval Bible manuscripts, which form the basis of modern printed editions. Although the Tiberian vocalization has come down to us as the standard form of written vocalization, the oral Tiberian reading tradition that it originally reflected was largely lost to knowledge in the later Middle Ages and Jewish communities read the Tiberian signs with other local traditions of pronunciation. The Tiberian reading tradition can now be reconstructed to a large degree on the basis of a variety of extant medieval sources. The reading tradition that is reconstructed from such sources does not correspond in many details to the descriptions of the pronunciation of Biblical Hebrew that appear in current reference grammars. In order to study the phonology of the Tiberian tradition of Hebrew, therefore, it is essential first to reconstruct through philological research the original form of the tradition. ${ }^{1}$

The Tiberian reading tradition of Biblical Hebrew has its roots in an ancient reading tradition that was transmitted orally in the first millennium c.E. before the creation of the written notation of vocalization signs. Another reading tradition of Biblical Hebrew was transmitted in Babylonia in the first millennium C.E., which, in the early Islamic period, came to be recorded in another type of sign notation created by Babylonian Masoretes, known as Babylonian vocalization. The Tiberian and Babylonian reading traditions are historically closely related and are likely to have derived from the same source, which can be identified as a proto-Masoretic type of reading existing in the Second Temple period. The Babylonian reading tradition has been preserved in numerous manuscripts with Babylonian vocalization. ${ }^{2}$ Although the Tiberian and Babylonian traditions are closely related, there are, nevertheless, numerous small differences in phonology and morphology between the two. Some of these differences can be attributed to historical change that took place in the traditions over the course of their transmission in the first millennium. It is also possible that some differences reflect variations that existed already within the ProtoMasoretic reading in the Second Temple period. What is of interest to us in this

1 For a description of the current state of philological research see Khan (2020). Short overviews can be found in Khan (2013a, 2013c).

2 For a comprehensive description of this vocalization see Yeivin (1985). Short overviews are provided by Khan (2013d) and Heijmans (2016). 
paper is that the Babylonian tradition differed from the Tiberian in a number of aspects of syllable structure and metrical structure.

\section{$1 \quad$ The Tiberian reading tradition}

In order to understand the syllable structure in the Tiberian reading tradition it is important to know the distribution of vowel length. Long vowels in the reading tradition include those that are represented by full vowel signs when they are either (i) in a stressed syllable or (ii) in an open unstressed syllable. Elsewhere a vowel represented by a full vowel sign is pronounced short. Examples:

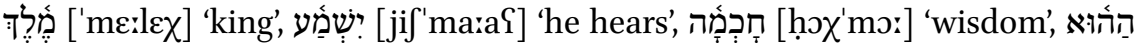

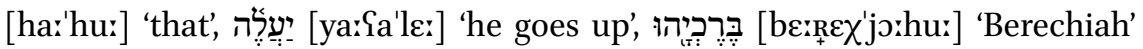
(1Chron. 2.24). ${ }^{3}$

In order to establish the synchronic phonological representation of the vowels of the Tiberian reading tradition one must distinguish between (i) vowels which are invariably long and include length in their underlying phonological representation and (ii) vowels whose length is determined by syllable structure and stress so are of unspecified length at a phonological level (Khan 2013e).

The long vowel phonemes include: long qameș $/ \bar{\partial} /$, holem $/ \bar{o} /$, șere /êe/, long

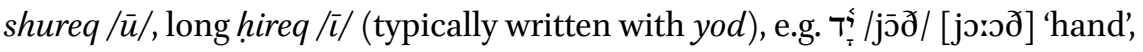

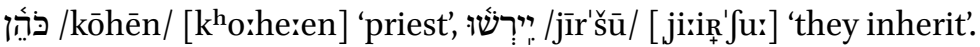

The vowel phonemes unspecified as to length include: patah /a/, seghol /e/, hireq /i/, qibbuss/shureq /u/. In principle these are long when syllabified with two moras in open syllables to compensate for historical gemination, e.g. הַוּא

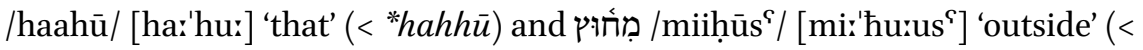

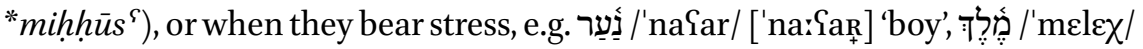
['me:lex] 'king'. In unstressed closed syllables they are short.

To the second category of vowels we should add also /e/ and /o/ without specified length. These are represented by the șere and holem vowel signs respectively in the stressed syllable of certain forms. Since stressed vowels are always long, on a phonetic level these are not distinguishable from șere and holem representing phonemes with underlying length. This is necessary to account for apparent discrepancies in the historical development of vowels in several morphological forms, in which patah (a vowel with no specified length feature) occurs in parallel with șere and holem (Sarauw 1939, 56-64; Khan 1994). This applies, for example, to nouns with an originally doubled final

3 For the evidence for this distribution of vowel length see Khan (1987). 
consonant. In forms deriving from the *qall pattern the vowel is patah, e.g. רָּ /'rav/ 'much', and in forms deriving from the *qill and *qull pattern, the vowel

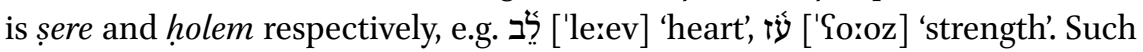
words would all have a vowel of unspecified length on the phonological level /'rav/, /'lev/, /' $\mathrm{Yoz} /$ and the length would have been a consequence of stress. There is, therefore, no discrepancy in their pattern. The same applies to the underlying phonological representation of the patah, șere and holem in verbal

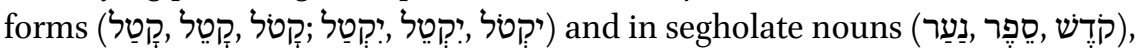
which would have the phonemes /a/, /e/ and /o/ respectively.

In syllables that do not have the main stress the vowels $/ \mathrm{e} /$ and $/ \mathrm{o} /$ are generally realized phonetically as $[\varepsilon]$ or $[0]$ respectively, which overlap in quality with

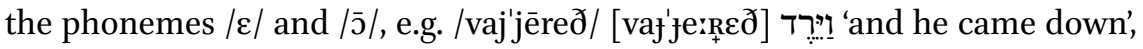

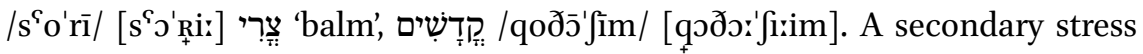

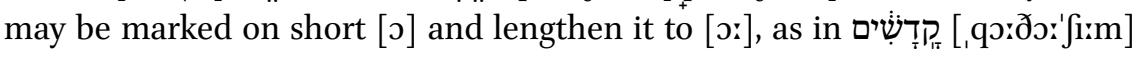
'holinesses' (Exod. 29.37).

Another key starting point for analyzing the syllable structure of the Tiberian reading tradition of Biblical Hebrew is understanding the original function of the shewa sign. The quality of vocalic shewa in the Tiberian tradition was generally the same as that of the patah vowel sign, i.e., the maximally low vowel [a]. When occurring before a guttural consonant or the letter yod it was realized with a different quality through an assimilatory process. Before a guttural it was realized as a short vowel with the quality of the vowel on the guttural, e.g. מבּ משאר

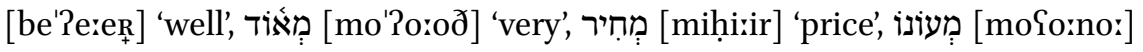
'his dwelling place'. Before yod it was realized as a short vowel with the quality of short hireq [i], e.g. בְּיוֹ [bi'jo:om] 'on the day'. The default pronunciation of vocalic shewa with the quality of [a] was equivalent to that of the hatef patah sign $\left(_{-.}\right)$. Both the vocalic shewa and the vowels expressed by hatef signs were short vowels that, in principle, had the same quantity as short vowels in closed unstressed syllables, which were represented in standard Tiberian vocalization

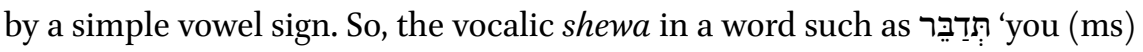
speak / she speaks' would have been read with the same quality and quantity as the patah in the closed syllable that follows it: [ $\mathrm{t}^{\mathrm{h}}$ aðabberen]. Likewise, the

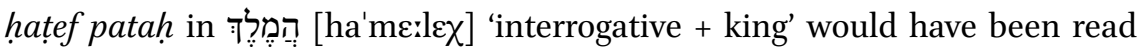

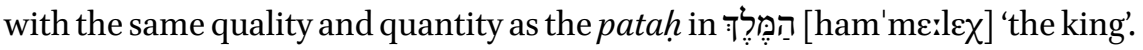
Evidence for this is found in the Masoretic treatise on the shewa published by K. Levy:

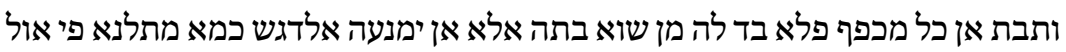

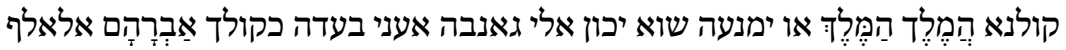
כפיף ולולא אלשוא אלדי בעדה געלנא לה שוא יכוא יכואה 
It is an establised fact that every letter that has a 'light' (i.e. short) vowel requires a shewa unless this is precluded by a dagesh (in the following let-

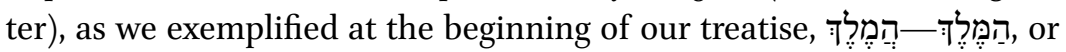

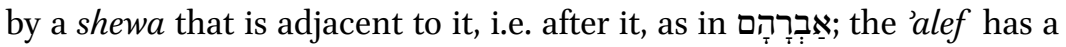
short vowel, and were it not for the shewa that comes after it, we would have given it a shewa. ${ }^{4}$

The author of this treatise did not feel that there was a quantity difference between the vowel written with the hatef sign and the vowel represented by the full vowel sign. In his view it was the syllable structure which necessitated the notational distinction and not the quantity of the vowel segment. The shortness of the vowel in a closed syllable was indicated by the dagesh or shewa on the subsequent consonant. For the sake of economy of notation no additional sign was added to the vowel sign.

Further evidence for the quantitative equivalence of shewa and hatef vowels, on the one hand, and short vowels represented by full vowel signs in closed unstressed syllables, on the other, can be found in the use of the shewa and hatef signs in a variety of non-standard Tiberian manuscripts from the Cairo Genizah. These manuscripts sometimes represent a short $/ a$ /vowel in a closed unstressed syllable with a hatef patah or a shewa sign. ${ }^{5}$ Even some of the standard Tiberian Masoretic codices contain a few cases of such a phenomenon,

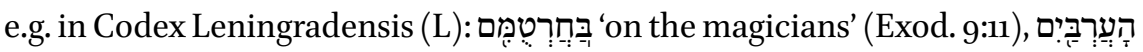

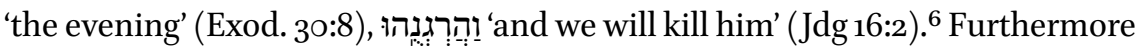
in medieval Judaeo-Arabic texts with Tiberian vocalization shewa and hatef patah are used to represent Arabic short / $a /$ in both open and closed syllables. ${ }^{7}$

In the Tiberian Masoretic literature a consonant with a vocalic shewa or a hatef vowel sign was not considered to stand independently, but was said to

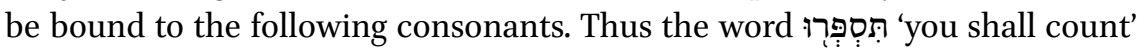
(Lev. 23.16) was considered to have been composed of two prosodic units [ $\mathrm{t}^{\mathrm{h}}$ is$\mathrm{p}^{\mathrm{h}}$ anuu:]. The sources refer to these prosodic units by the Arabic term maqtaS, which is used in the Arabic grammatical literature to refer to a syllable. The treatise Hidāyat al-Q̄a ri' 'The Guide for the Reader', written by the Karaite grammarian 'Abū al-Faraj Hārūn in the first half of the eleventh century C.E., notes that syllables thus formed have the status of words, i.e., they can stand independently:

4 Levy (1936, כה). The lacunae in Levy's text can now be supplied from the Geniza manuscript, CUL Or. 1080. 13.3, fol. 2v; cf. Yeivin (1981, 46), Eldar $(1988,127)$.

5 See Khan (1991) and Blapp (2017) for examples.

6 Yeivin $(1968,18)$, Dotan $(1985)$.

7 For examples see Khan (1992, 2010). 


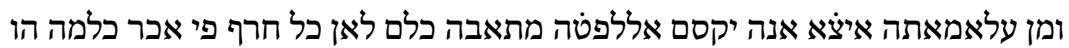

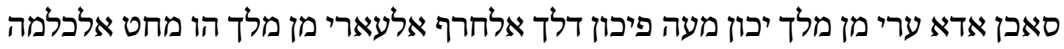

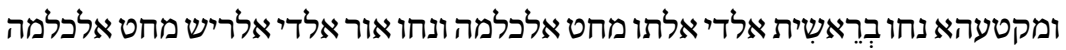

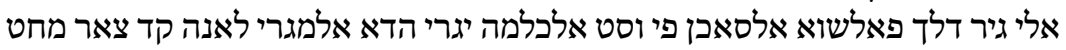

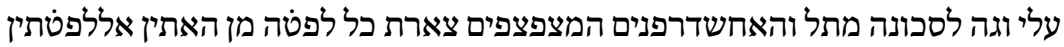

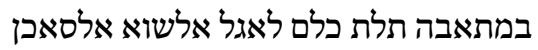

Another of it features is that it divides a word into (units) that have the status of words. This is because every letter at the end of a word is quiescent when it is deprived of an accompanying vowel and this letter that is deprived of a vowel is the stopping point (mahatt ) of the word and its

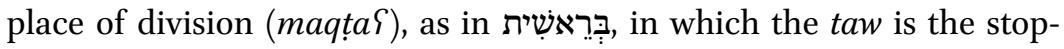
ping point of the word, and in which the resh is the stopping point of the word, as so forth. A quiescent shewa in the middle of a word has the same status, for it is in a sense a stopping point on account of its quies-

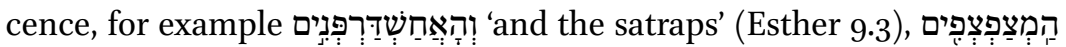
'those who chirp' (Isa. 8.19). Each of these two expressions has the status of three words (kalim) on account of the quiescent shewa

Hidāyat al-Qāri', Long version, ed. Khan 2020, § II.L.2.10.3

In various passages in Hidāyat al-Qäri' there are references to the fact that a vocalic shewa or hatef vowel is read more quickly than a following full vowel sign, e.g. 'The shewa makes a letter mobile and causes it to be uttered quickly, so that one cannot tarry on that letter', 'The shewa moves quickly forwards'. By contrast a vowel is read more slowly, e.g. 'A vowel has an indissoluble feature, namely slowness and steadiness. ${ }^{10}$ These descriptions can be interpreted as referring to the rhythmic structure of the prosodic unit consisting of a vocalic shewa followed by a vowel whereby this unit is a prosodic foot consisting of an iambic metrical pattern with a weak syllable followed by a strong syllable, which can be represented $\left(.{ }^{*}\right)$. On a prosodic level, therefore, a word such as

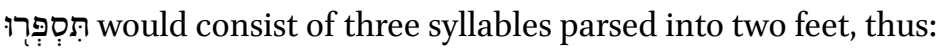

(1) [this. $\mathrm{p}^{\mathrm{h}}$ a.'Ru: $]$

$\left({ }^{*}\right) \quad\left(\cdot{ }^{*}\right)$

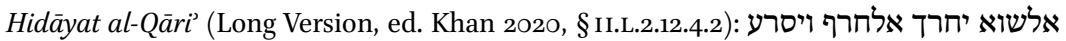
בנטקה חתי לא ימכן אחד אן ילבת בדלך אלחרף.

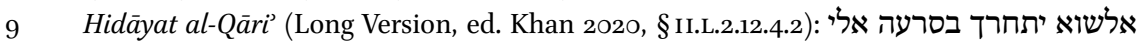
קדאם.

10 Hidāyat al-Qāri' (Long Version, ed. Khan 2020, § II.L.2.12.7): ללמלך עלה לא תפארקה והאתי אלתבאטי ואלתבאת. 
In the representation above of the prosody of is it will be noticed that the first syllable by itself has the status of a foot, i.e. [( $\left.\mathrm{t}^{\mathrm{h}} \mathrm{is}\right) \cdot\left(\mathrm{p}^{\mathrm{h}} \mathrm{a}\right.$.'R⿱ $\left.\left.\mathrm{p} u\right)\right]$, where feet are marked by rounded brackets. This is in conformity with the current state of research on the typology of the metrical phonology of the world's languages. The foot ( $\mathrm{p}^{\mathrm{h}} \mathrm{a}$.'nu: $)$, as remarked, is iambic, i.e. it consists of two syllables, of which the second is the stronger. It is a binary foot consisting of a light syllable with one mora, viz. CV, and a heavy syllable consisting of two mora, viz. CVV. It is represented here $\left(.{ }^{*}\right)$, where the star * represents the strong prominent syllable and the dot the weak syllable. In many languages with metrical phonology with binary feet, the feet may be binary either in the number of their syllables, as in the foot (CVCVV), which is known as a syllabic foot, or in the number of their morae, known as a moraic foot. This means that a heavy syllable with two morae, viz. CVV or CVC, normally represented in metrical phonology by $\left({ }^{*}\right)$, could function as a foot in the metrical scansion of a word

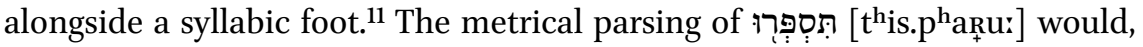
therefore, be $\left[\left({ }^{*}\right),\left(.{ }^{*}\right)\right]$. The CVC syllable with a vowel $\left[\mathrm{t}^{\mathrm{h}} \mathrm{is}\right]$, which constitutes an independent foot, would be metrically stronger than the first syllable of the foot $\left(.{ }^{*}\right)$, which is represented by a shewa sign. This would conform to the medieval descriptions cited above, which state that a vowel has the feature of 'slowness and steadiness' whereas a shewa 'moves quickly forwards'. These differences in prominence can be represented by a metrical grid. ${ }^{12}$ In the grid the relative prominences are marked by differences in heights of columns of index marks:

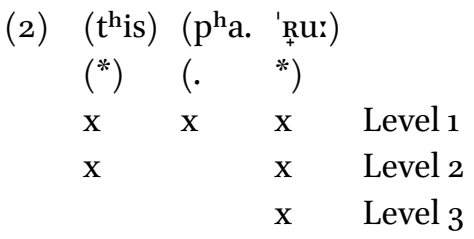

As can be seen, the syllable with the main stress is the most prominent. This stress occurs on the strong syllable of the $\left(.{ }^{*}\right)$ foot.

The Masoretic notion of maqta 9 , therefore, can be equated with the notion of foot in the prosodic hierarchy rather than syllable. The foot is of relevance for some phonological processes in the Tiberian pronunciation tradition. This is a

11 For the typology of feet in iambic metrical systems see Hayes (1985, 1995), Kager (1993, 383, 2007, 200-201).

12 For hierarchical arrangement of linguistic rhythm on a grid see, for example, Liberman and Prince (1977), Hayes (1995, 26-31) and Halle and Vergnaud (1987). 
key justification for the reality of such metrical constituents (Nespor and Vogel 2012). The occurrence pattern of the allophones of Tiberian resh is a clear example of this. Tiberian resh had an advanced uvular allophone [R] , which can be considered its default realization, ${ }^{13}$ and a pharyngealized, apico-alveolar allophone $\left[\mathrm{r}^{\mathrm{S}}\right]$, which was conditioned by certain environments (Khan 1995, 2013b). According to the medieval sources the apico-alveolar allophone occurred when resh is preceded by the consonants דזצתטסלן or followed by and when either resh or one of these consonants has shewa. This can be reformulated as the rule that apico-alveolar resh occurs when in immediate contact with a pre-

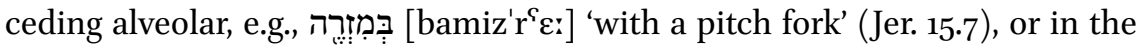
same foot as a preceding alveolar, e.g., when the resh is in immediate contact with or in the same syllable as a fol-

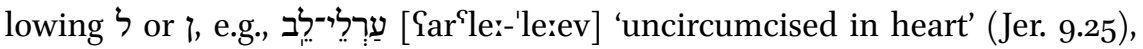
רַ [r' $\mathrm{r}^{\varsigma}$ anna'nu:] 'rejoice (mpl)!' (Ps. 33.1). What is of significance for the reconstruction of prosodic structure is that a resh preceded by an alveolar consonant with vocalic shewa was realized with the apico-alveolar allophone, e.g., צִּרוּפָּה

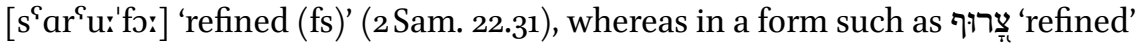
(Ps. 12.7), where the alveolar has a vowel sign, the resh has its default realization as an advanced uvular [s's'riquif]. This reflects the fact that one of the conditions for the occurrence of apical resh is, indeed, that it occurs in the same

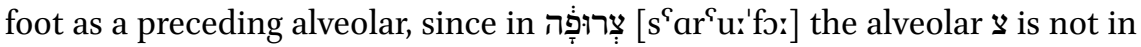
the same phonetic syllable but is in the same foot as the following resh-it is bound to the resh by the shewa, according to the description of the medieval

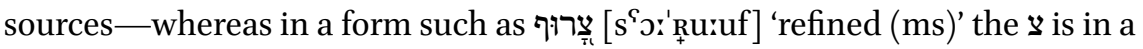
separate foot from that of the resh.

The distribution of the allophones of resh, therefore, reflects the phonological reality of the notion of foot (maqtaS) in the Masoretic sources, viz., that a consonant with vocalic shewa belongs to the foot of the segments immediately following it.

The vocalic shewa can be regarded as having the synchronic status of an epenthetic vowel. In many cases vocalic shewas in the Tiberian reading tradition occur where historically there were originally lexical vowels. These vow-

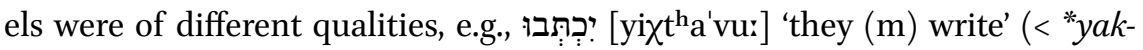

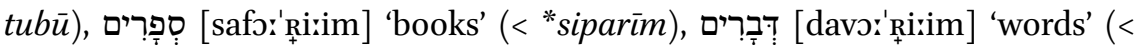
*dabarim). The vocalic shewa, however, does not preserve the quality of the historical lexical vowel; rather, the shewa is a vowel with a neutralized quality, i.e.,

13 Cf. Hidāyat al-Qāri', long version (ed. Khan 2020, § II.L.1.9.5): פהדא מא כלאמהם עליהא ... 'This is their normal pronunciation (of the letter)'. 
the maximally open vowel [a], in some circumstances modified by assimilation to its phonetic environment. As remarked, before a guttural it was realized as a short vowel with the quality of the vowel on the guttural and before yod it was realized as a short vowel with the quality of short hireq [i]. Shortness and nonrounded vowel quality and also the copying of the quality of an adjacent vowel are characteristic features of epenthetic vowels (Hall 2011, 1581). In examples such as those cited for the reduction of lexical vowels to epenthetic vocalic shewa, the motivation for the vowel is no longer lexical but rather phonotactic, in that it breaks illicit clusters of consonants on the phonetic level. Lexical vowels can be reduced to zero in contexts where licit sequences of consonants

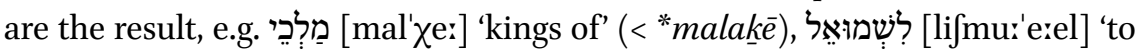
Samuel' (< * (a-Šamüèl). According to this analysis of vocalic shewa, it would have to be assumed that the original vowel is absent at some underlying level of the phonological derivation of words and an epenthetic vowel is introduced at the phonetic surface level. A /CC/ cluster at the onset of a syllable in word-initial position is broken by an epenthetic and this can be represented thus:

\section{(3) /mqō.mō/ [ma.qo:.'mo:] 'his place' מְiph}

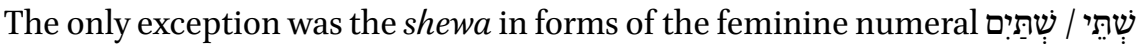

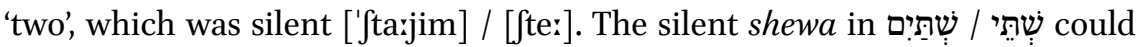
be explained by the analysis of the shin as extrasyllabic and not part of the onset of the syllable. Moreover, if the cluster / $\mathrm{f} /$ were considered an onset, this would violate the normal principle of rising sonority of syllable onsets (Ewen and Hulst 2001, 136-141, 147-150; Hoberman 1989):

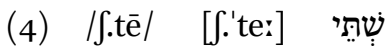

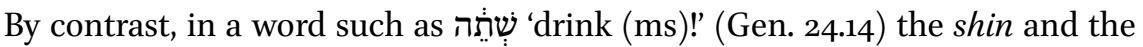
taw form the onset of a syllable and are split by an epenthetic: / $\int \theta \bar{e} /\left[\int \mathrm{a}\right.$.' $\left.\theta \mathrm{e}:\right]$. We should mention here the exceptional form [?זָרוֹ thetic 'alef, which is attested in the Tiberian Masoretic text as a variant of [za.'r' ${ }^{\varsigma}$ O..aY] (Job 31.22; Jer. 32.21).

One could argue that the conditioning of the allophones of the resh discussed above operated within the domain of the underlying syllable and ignored epenthetics introduced at the phonetic level, operating on a word such

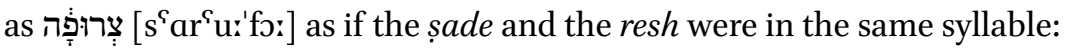

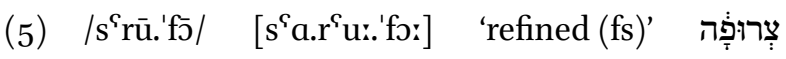


Since, however, the allophones of resh are themselves a phonetic phenomenon, it is more satisfactory to regard the prosodic foot on the phonetic level as the relevant domain rather than a more abstract underlying level.

In word-internal position the sequence /CCC/ is always syllabified /C.CC/, i.e. the second consonant is syllabified as an onset, and the cluster of the second and third consonants at the onset of the second syllable are split by a vocalic shewa, e.g.,

/yix.tvū/ [yix.tha.'vu:] 'they (m) write'

A shewa under a geminated letter with dagesh within a word was likewise

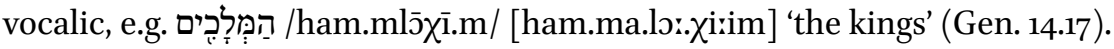

As remarked, although vocal shewa was a vowel on the phonetic level, it would be zero at a deeper phonological level, and so phonologically equivalent to quiescent shewa. It could have been this underlying phonological level that the marking of the shewa sign in the Tiberian vocalization was originally intended to represent and it could have been for this reason that the Masoretes used the same sign for both types of shewa (Khan 1987, 1991).

When shewa occurred within a word after a long vowel, it was generally

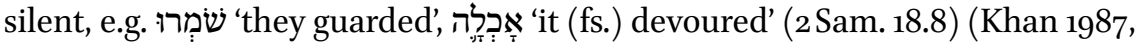
54-55), with the result that the long vowel appears to be in a closed syllable. Likewise some long vowels appear to occur in closed syllables at the end of a

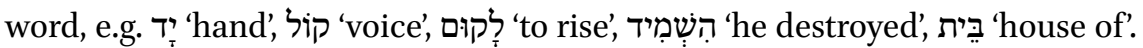
Such syllables should be analysed as containing an epenthetic before the final consonant of the same quality as that of the preceding vowel, viz. [for.om.'puu],

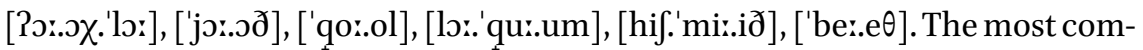
pelling evidence for this analysis is the appearance of this epenthetic as patah before guttural consonants (the so-called furtive patah), e.g. רוּ ['Ṛu..ah] 'spirit', due to assimilation to the vocalic tract configuration of the guttural (for further details see Khan 1987). Metrically a phonetic sequence /CV..VC/ with such an epenthetic can be supposed to constitute a trochaic foot consisting of a strong + weak syllable $\left({ }^{*}\right.$.).

The presence of the epenthetic in word-medial syllables in words such as שִמְרִים [Jor.om.'pii..im] is demonstrated by the fact that the first syllable can take a secondary stress in the form of a conjunctive accent, e.g.

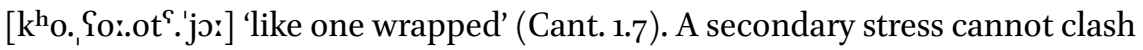
with the main stress but must in principle be separated from it by another syllable.

The underlying syllable structure of words such as קוֹמִרים and could be represented thus: /qō.l/, / ō.m.rī.m/, with stray extrasyllabic consonants. This 
would have been conditioned by a constraint against superheavy syllables consisting of codas greater than two morae. Following the analysis by Kiparsky (2003) of Arabic syllable structure, we may say that such unsyllabifiable consonants are licensed by moras adjoined to the higher node of the prosodic word rather than the syllable node. Kiparsky refers to these consonants as 'semisyllables':

(7) /(qō).l/ ['qox.ol] 'voice'

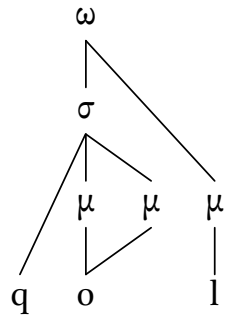

$/\left(\int \bar{\jmath}\right) \cdot m .(r \bar{u}) /\left[\int \jmath x . . m m .{ }_{+}^{\prime} u_{x}\right]$ 'they guarded'

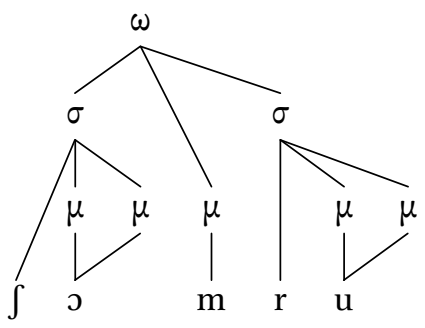

On the phonetic level the extrasyllabic consonants were syllabified by means of epenthetics. There was a constraint against word-final short CV syllables, since such syllables had to be combined in an iambic foot with a following bimoraic syllable. So the epenthetic came before the consonant, forming a trochaic foot on the phonetic level: ['qox.ol] (* .). This process of epenthesis in word-final position was extended by analogy to similar syllabic configurations in wordinternal position.

The discussion above concerning the epenthetic vocalic shewa has been concerned so far with cases in which it has developed from a historical lexical vowel. Another motivation for an epenthetic vowel was to introduce an ahistorical vowel between two consonants for orthoepic purposes. This applies in particular to the frequent insertion of an epenthetic after a guttural consonant (אהעח) where there was no historical lexical vowel in a sequence where the guttural originally closed a syllable in word-medial position and was in contact with a following consonant. These epenthetics are regularly written 
with hatef signs in the standard Tiberian tradition. The process can be analysed as involving the following stages.

(i) The historical syllable structure reflects the morphological pattern of the

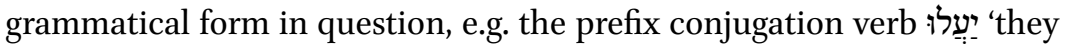
go up' would have the historical syllable structure *ja\}.lü, in line with, for example, ישישתו' 'they drink'. This can be regarded also as the underlying phonological syllable structure /jâ.lū/.

(ii) A short epenthetic is added after the guttural. This creates a short open phonetic syllable [CV], viz. [ja.Sa.lu:].

(iii) The vowel in the syllable preceding the guttural is lengthened, viz. [ja:.Sa.lu:]. This is likely to have come about due to a metrical constraint on having a sequence of a light CV syllable and a following weak epenthetic syllable.

In such syllabifications involving gutturals in word-medial position the epenthetic copies the quality of the preceding vowel:

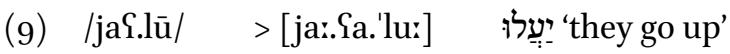

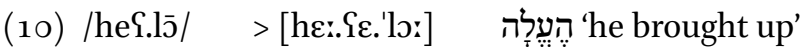

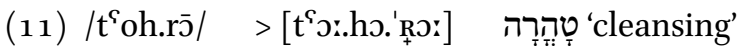

The motivation for the introduction of the epenthetic between a guttural and a following consonant was orthoepic. Gutturals were weak consonants in the reading tradition and efforts were made to ensure that they were not slurred over. Acoustically the epenthesis made the gutturals more perceptible when separated from the following consonant ${ }^{14}$ and this facilitated their preservation in the reading.

Although there is a tendency for gutturals to be followed by hatef vowels where parallel forms have silent shewa, this is not a universal rule. It is sometimes possible to identify additional phonotactic and metrical factors that appear to have conditioned the occurrence of the hatef vowels in certain forms with gutturals in contrast to other forms that have silent shewa. As shown by de Caen (2003) and Alvestad and Edzard (2009) one factor that conditions the occurrence of hatef vowels on gutturals, at least on het, is sonority of the following consonant. They have shown that a hatef vowel tends to occur when the

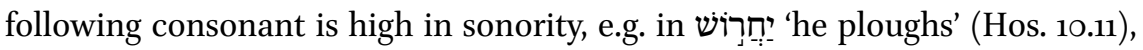

14 Cf. Hall (2011, 1577-1578), who discusses this function of epenthesis in languages. 
where the consonant is a sonorant rhotic, but exhibits a greater tendency to be omitted when the following consonant is lower in sonority, e.g. יחי 'he ceases' (1Sam. 9.5). This is motivated by the principle that the optimal contact between two adjacent syllables is where the onset of the second syllable is stronger than the offset (coda) of the preceding syllable (Vennemann 1988, 40), and so the contact is eliminated with a following weak sonorous onset by the intervening hatef vowel.

Variations, however, occur in inflections of the same verb, where the same

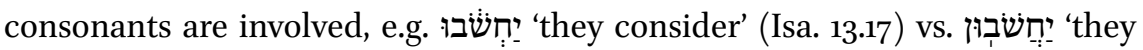
consider' (Psa. 35.20). In such cases the hatef appears to have been motivated by a metrical factor, namely the disfavouring of a rhythmic clash. This is seen in a metrical grid representation of the two forms. In these grids feet are marked in the first row. It will be assume that feet after the main stress are extrametrical (marked with angular brackets \langle\rangle ). Evidence for this extrametricality is presented below.

(12) jah. 'Jo:. vu:

$\begin{array}{llll}\left(^{*}\right) & \left(^{*}\right) & \left\langle{ }^{*}\right\rangle & \\ \mathrm{x} & \mathrm{x} & \mathrm{x} & \text { Level 1 } \\ \mathrm{x} & \mathrm{x} & \mathrm{x} & \text { Level 2 } \\ & \mathrm{x} & & \text { Level 3 }\end{array}$

(13) ja:. ha fo:. 'vus. un

$\begin{array}{llllll}\left({ }^{*}\right) & (. & \left.{ }^{*}\right) & \left({ }^{*}\right. & .) & \\ \mathbf{x} & \mathrm{x} & \mathrm{x} & \mathrm{x} & \mathrm{x} & \text { Level 1 } \\ \mathrm{x} & & \mathrm{x} & \mathrm{x} & & \text { Level 2 } \\ & & & \mathrm{x} & & \text { Level 3 }\end{array}$

The grid representation displays the varying degrees of the relative prominence of syllables. These include epenthetic syllables, syllables containing a vowel without the main accent, and syllables with the main accent (represented as levels 1,2 and 3 respectively in the grids above). It is likely that the insertion of the syllable with the hatef vowel in the second form was favoured since it created grid euphony by repairing a potential rhythmic clash caused by two syllables of the same prominence before the stress, ${ }^{15}$ as shown in the following grid:

15 A clash is the occurrence of two adjacent metrically strong elements with the same prominence. A lapse is the occurrence two adjacent metrically weak elements; cf. Prince (1983), Selkirk (1984). 
(14) *jah. for. 'vus. un

$\begin{array}{lllll}\left({ }^{*}\right) & \left({ }^{*}\right) & \left({ }^{*}\right. & .) & \\ \mathrm{x} & \mathrm{x} & \mathrm{x} & \mathrm{x} & \text { Level 1 } \\ \mathrm{x} & \mathrm{x} & \mathrm{x} & & \text { Level 2 } \\ & & \mathrm{x} & & \text { Level 3 }\end{array}$

In the standard Tiberian tradition a shewa is in principle silent on a guttural when the syllable of the guttural receives the main accent and it is followed

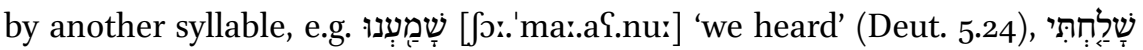
[Jj.'la:.ah.thi:] 'I sent' (Num. 22.37). If the accent moves forward after the

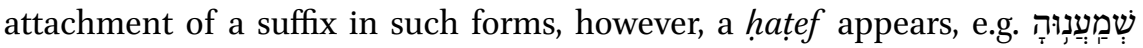
[Ja.ma:.fa.'nux.ho:] 'we heard it' (Psa. 123.6). These phenomena can also be explained on metrical grounds if we posit, as remarked above, that syllables after the main accent are extrametrical and unfooted. Extrametrical syllables at the right periphery of words commonly occur in iambic metrical systems (Kager 2007, 204). The word שָׁמָמְנוֹ can be represented thus (extrametrical syllables in angular brackets):

(15) Jo. 'ma:. af. nu:
$\left({ }^{*}\right) \quad\left({ }^{*} \quad\right.$. $) \quad\left\langle{ }^{*}\right\rangle$

Here, since the syllable following the guttural is extrametrical and unfooted there is no rhythmic motivation for a hatef, which is a weak syllable that is obligatorily footed and metrically bound to a following strong syllable.

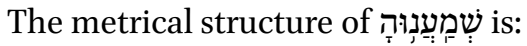

(16) Ja. ma:. fa. 'nu:. ho:

$\left(.{ }^{*}\right) \quad\left(.{ }^{*}\right) \quad\left\langle{ }^{*}\right\rangle$

Here the accent on the syllable after the guttural licenses the hatef in that it can be footed and bound metrically to this strong footed syllable.

Some short vowels in open syllables are lexical vowels rather than epenthetic vowels. This applies mainly to a set of vowels represented by hatef qameș. In such cases the hațef qameș [0] preserves the rounded quality of a historical lexical vowel of the morphological form and there has not been quality reduction and neutralization. They should be represented as the short phoneme /o/ in the phonological form of the word, e.g.

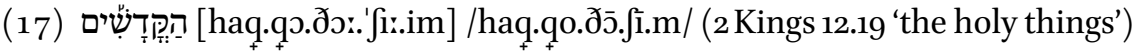

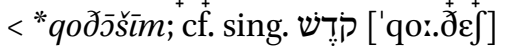




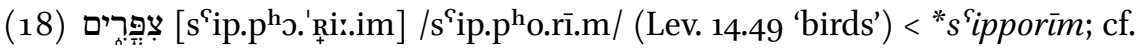

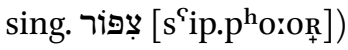

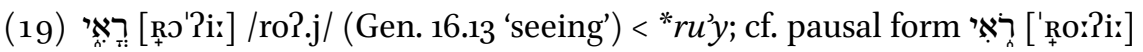
(1Sam. 16.12)

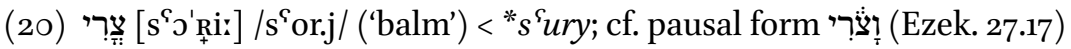

In the examples cited above the hat ef qames is the reflex of a short round historical vowel. In a few cases hatef qameș in an open syllable is the result of the shortening of an original [o: $/ \overline{0} /$ or $[\mathrm{o:}] / \overline{\mathrm{j}} /$ in an unstressed syllable, e.g.

(21)

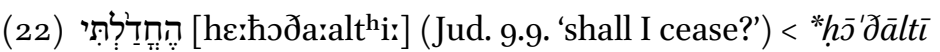

Yeivin (1980, 283) identifies some cases of hațef seghol on non-guttural consonants as a lexical vowels ('morphological use' in his terminology). These are

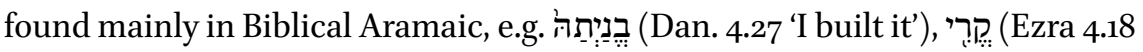

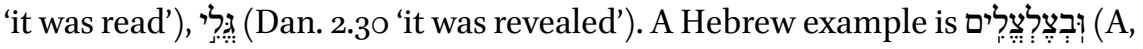

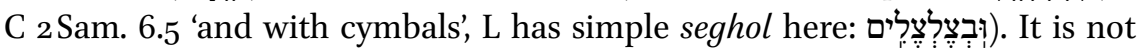
clear, however, whether these preserve the original quality of a lexical vowel or whether they reflect some kind of assimilation to the phonetic environment.

The qualities of hat ef qames [o] and hatef seghol $[\varepsilon]$ share the property of being lax vowels, in that they were produced in the central vowel space.

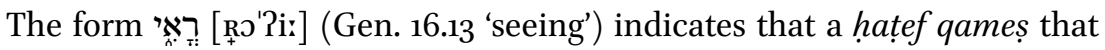
represents a lexical vowel does not assimilate to the quality of the vowel after a following guttural, unlike epenthetic vowels.

The status of lexical vowel of these cases of hațef qameș involved not only the resistance to neutralization of their historical vowel quality and to assimilation to the quality of adjacent vowels but also retention of a stronger metrical structure than epenthetics. This is demonstrated by the distribution of the allophones of resh. In the medieval sources the resh was said to have its default

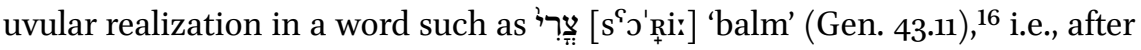
an alveolar consonant with hatef qameș. As remarked above, when the alveolar

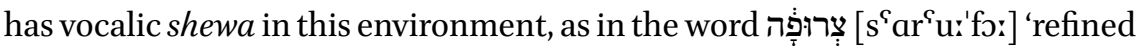

16 See the commentary on Sefer Yeșira by Saadya Gaon (ed. Lambert 1891, 79) and the sources cited in Khan (1995, 70-71). 
(fs)' (2 Sam. 22.31), the resh was in the same foot as the alveolar and had a pharyngelized apico-alveolar realization. This reflects the fact that the domain of the conditioning of the allophones of resh was the foot rather than the syllable:

(23) $\left[s^{\mathrm{s} a . r^{\mathrm{s}} u . .} \quad\right.$ 'fo: $]$

$\left(.^{*}\right)$

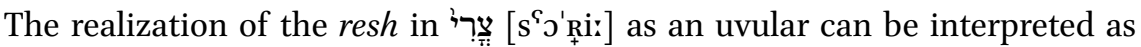
reflecting the fact that such a hatef qames on a non-guttural consonant was in a separate foot from that of the following syllable:

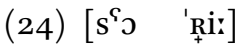

$(*) \quad(*)$

The foot containing the hatef qames consists of a light monomoraic syllable CV. Metrical phonologists term this a 'degenerate foot', since feet would normally be expected to be bisyllabic or bimoraic (Prince 1990; Kager 2007, 200-201). Such degenerate feet are tolerated in some languages, but often only under certain conditions, such as peripheral position or main stress. In Tiberian Hebrew a degenerate foot consisting of a light $\mathrm{CV}$ syllable is only tolerated with a lax vowel quality of qameș or seghol.

A series of two light CV syllables is not tolerated, and a foot with the syllabic structure CVCV is not licit. So a degenerate CV foot cannot be combined with a preceding monomoraic syllable of a vocalic shewa of a preposition or a short $/ u /$ of the conjunctive waw. In such cases the hațef qameș vowel is elided and in this respect it behaves like a vocalic shewa, e.g.

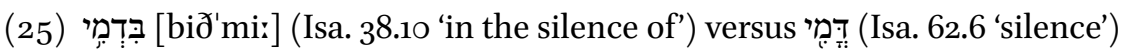

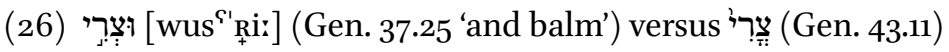

Another repair strategy is to lengthen a preceding short vowel, as is found when the degenerate foot is preceded by interrogative he, e.g.

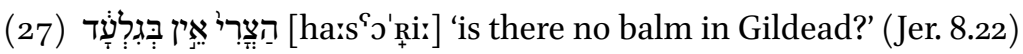


In this section of the paper I shall briefly examine some of the features of the syllable and metrical structure of the Babylonian tradition of Biblical Hebrew that are distinct from the Tiberian tradition. The medieval manuscripts with Babylonian vocalization reflect a wide diversity of traditions, many of which, exhibit convergence with the Tiberian reading tradition. I shall concentrate on those features that are characteristically Babylonian. These are found in particular in manuscripts belonging to the earlier layers of the tradition (indicated below by the abbreviations $\mathrm{OB}=$ Old Babylonian and $\mathrm{MB}=$ Middle Babylonian). There are no prescriptive descriptions of the Babylonian pronunciation in Masoretic treatises and the pronunciation has to be reconstructed almost exclusively from the vocalization appearing in the manuscripts.

Whereas in the Tiberian tradition word-initial consonant clusters are broken by epenthetic vowels, it appears that there was no epenthetic in this context in Babylonian. This can be inferred, for example, from a vocalization such as the following (Yeivin 1985, § 8.13):

(28) יסוֹד [isso:ð] OB 'the base of' (Lev. 4.25 | יסוֹד [yaso:oð])

Here the yod is vocalized with hireq, which appears to have arisen due to the fact that this initial consonant clustered with the second consonant without an epenthetic [jso:ð] > [i:so:ð].

Another feature that reflects the lack of a vowel where Tiberian has vocalic shewa is the phenomenon of epenthesis of vowels in forms such as the following (Yeivin 1985, 390):

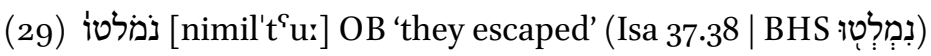

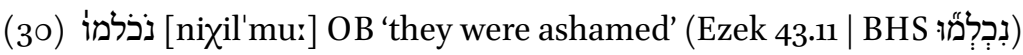

This type of epenthesis is found mainly before the sonorant letters lamed, nun, resh and mem. It arose due to the fact that Babylonian had a different typology of syllabifying word-internal CCC sequences. Unlike Tiberian, which syllabified the second consonant as an onset, viz. C.CC, Babylonian syllabified it as a coda, viz. CC.C. This coda was a cluster, but when it had rising sonority an epenthetic was inserted to repair the violation of the sonority principle. A form such as נמלטו [nimil't $u$ : can be represented as having an underlying form such as the following: 
(31) /niml.'t' t'u: [ni.mil.'t' $u:]$

The lexical vowel of the closed syllable /niml/ remains short when the epenthetic is added at the phonetic level.

The first vowel in a form such as jמלטi [nimil't $t^{\uparrow} u$ :] was short. This is shown by manuscripts with the so-called compound Babylonian vocalization, which explicitly marks short vowels, e.g.

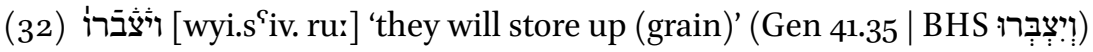

The metrical structure of a form such as נמלטו [ni.mil.'t $t^{\varsigma} u$ : could be represented as follows:

(33) ni. mil. ' $t^{\varsigma} \mathrm{u}$ :

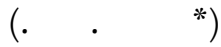

$\mathrm{X} \quad \mathrm{X} \quad \mathrm{X}$

$\mathrm{x}$

$\mathrm{x}$

In the Babylonian tradition, therefore, a sequence of two weak syllables was tolerated, unlike in Tiberian. So the word above would, presumably, have formed a single anapaest foot (.. *). Two adjacent weak syllables, however, would have constituted a rhythmic lapse and, although tolerated, there appears to have been pressure to repair this by eliding the first of the weak syllables, as shown by forms such as the following, in which the first consonant is vocalized with a shewa sign or left without any sign:

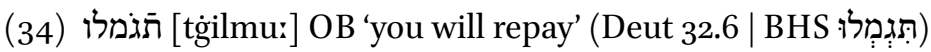

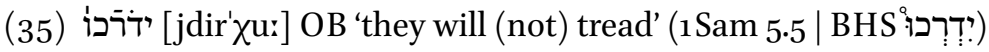

Similar syllabifications are found where yod occurs in word-medial position (Yeivin 1985, 389), e.g.

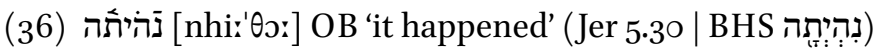

The underlying syllabification of this would be /nihy.' $\theta \bar{\jmath} /$, which would be realized phonetically with an epenthetic [ni.hiy.' $\Theta$ s:], and the first short vowel was then elided, resulting in [nhis.' $\theta$ s:].

A form such as יסוֹד [i.so:ð] can be interpreted as having an underlying syllabification thus /j.so:ð/ with the initial cluster C.C. The first consonant would, 
therefore, be extra-syllabic, and the long [i: $]$ on the phonetic level would have arise through a prosthetic vowel [ij.so:ð].

Babylonian, therefore, has a 'coda typology' of syllabification, which means that word-medial CCC sequences are syllabified CC.C and epenthetics are added to the coda (Hall 2011, 1580), e.g. CeC.C, rather than to the onset, e.g. Tiberian C.CeC (where e = epenthetic). This can be interpreted as reflecting a right-to-left typology of syllabification, whereby syllables are computed starting at the end of the word (Itô 1989). This typology would explain also the syllabification of word-initial clusters C.C, in that the second consonant is first taken as the onset of the syllable following it, computing from the right, and the remaining stray syllable is left extra-syllabic. By contrast Tiberian has a onset typology, which is left-to-right syllabification, whereby syllables are computed starting at the beginning of the word.

A similar phenomenon of the coda type of syllabification is reflected in the pattern of vocalization of guttural consonants, such as the following (Yeivin 1985, 313):

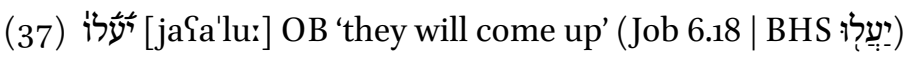

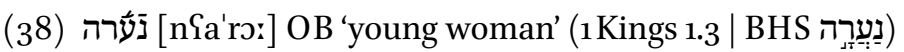

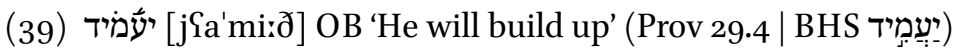

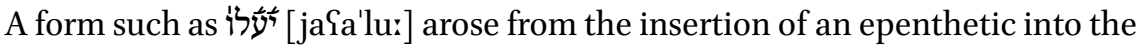
underlying form /yaSlü/. The purpose of the epenthetic on the guttural, as in Tiberian, was to make the guttural more perceptible. In Tiberian the guttural is syllabified with the onset of the following syllable, i.e. /CVGC/ > /CV.GC/ (where $\mathrm{G}=$ guttural) and an epenthetic is inserted after the guttural in the onset. The first vowel is lengthened due to a metrical constraint on having a sequence of a light $\mathrm{CV}$ syllable and a following weak epenthetic syllable: [CVV.GaC]. In Babylonian the guttural is syllabified with the coda of the preceding syllable and the epenthetic is added after the coda, thus /CVGC/ > /CVG.C/ [CVGa.C]. The first vowel remains short when the epenthetic is added.

This results in a metric structure containing a sequence on the phonetic level of two weak open syllables with short vowels:

(40) ja. Sa. 'lu:

(. $\quad * \quad *)$

$\mathrm{X} \quad \mathrm{X} \quad \mathrm{X}$

$\mathbf{X}$

$\mathbf{X}$ 


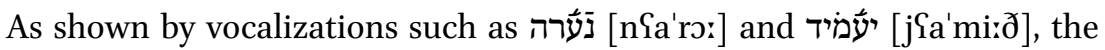
first weak syllable is optionally eliminated:

(41) n. Sa. 'ro:

$\begin{array}{cc}\cdot & * \\ \mathrm{x} & \mathrm{x} \\ & \mathrm{x} \\ & \mathrm{x}\end{array}$

In word final position there is likewise tolerance of two weak post-stress syllables, which is not licit in Tiberian. This results in forms such as the following (Yeivin 1985, 313):

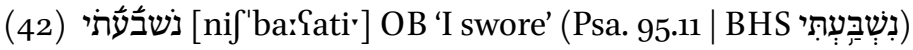

The metrical structure of this can be represented thus:

(43) nif. 'ba:. Sa ti'

$\left({ }^{*}\right) \quad(*) \quad\langle. \quad$.

$\begin{array}{llll}\mathrm{X} & \mathrm{X} & \mathrm{X} & \mathrm{X}\end{array}$

$\mathrm{x} \quad \mathrm{x}$

$\mathrm{X}$

This contains two weak and presumably unfooted syllables after the main accent. Since there is no absolute constraint against this in the Babylonian tradition, the guttural is followed by a vowel, unlike in Tiberian, where it is not licit due to the strict metrical constraint against two weak post-stress syllables.

The coda typology of Babylonian is also reflected in word-final syllables with long vowels. Babylonian does not have furtive patah in such syllables, as is the case in Tiberian. Rather, when the final consonant is fayin, patah is added after the Sayin (Yeivin 1985, 327-328), e.g.

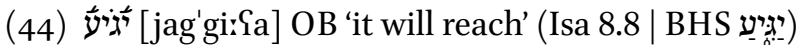

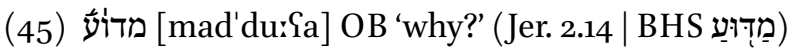

It occurs also when the long vowel before Sayin is qameș or pataḥ, e.g.

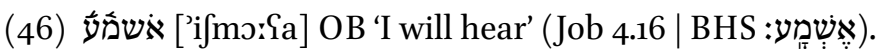


A form such as 站 [jag'gi:fa] would have the underyling syllabic structure /jag.gi:S/ and the epenthetic short [a] is added to the coda of the final syllable. This would result in the syllabification [jag.'gi..Sa] on the phonetic level. The short epenthetic can stand in word-final position since it does not have to be in the onset of a syllable as it does in Tiberian. The proposed underlying syllabification /jag.gi:S/ would not be subject to a constraint against closed syllables with long vowels. This analysis is supported by the fact that when gutturals other than Sayin that are preceded by long vowels occur in word-

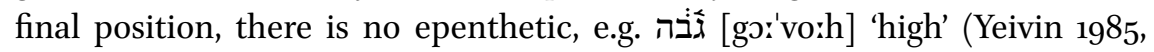

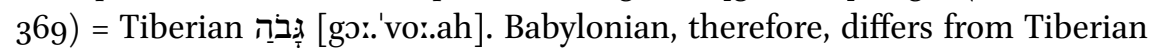
in its tolerance of CVVC syllables. Tiberian regularly eliminates CVVC syllables by syllabifying the final consonant as a semi-syllable, i.e. CVV.C. According to the interpretation of the syllable structure of Babylonian presented here, Babylonian does not have semisyllables after long vowels. One may explain this difference between the typologies of Tiberian and Babylonian in an optimality framework as the different ranking of constraints. In Tiberian the constraint against CVVC outranks a constraint against semisyllables. In Babylonian, by contrast, a constraint against semisyllables outranks a constraint against CVVC.

The Babylonian tradition, therefore, exhibits a different typology of syllabification and metrical structure from that of Tiberian. It exhibits a right-to-left computation of syllables resulting in a 'coda typology,' whereby the second consonant of a word-internal sequence /CCC/ is syllabified as a coda, viz. /CC.C/, and word-initial clusters are syllabified C.C, with the first consonant extrasyllabic. Tiberian, on the other hand, exhibits an on 'onset typology', where word-internal /CCC/ clusters are syllabified /C.CC/ and word-initial clusters are syllabified within the onset /CC-/. These variations in syllable typology within varieties of the same language have been identified also, for example, in modern spoken Arabic dialects (Kiparsky 2003; Watson 2007; Hall 2011). The coda typology of syllabification is reflected also by some Latin and Greek transcriptions of Hebrew from an earlier period, as in the following forms:

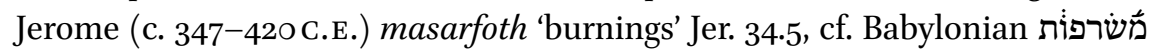

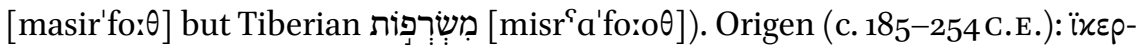

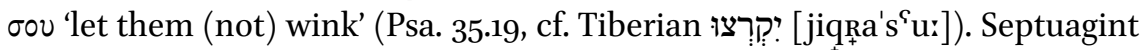

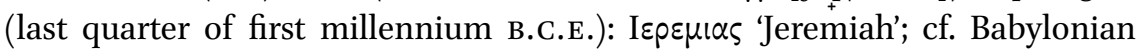

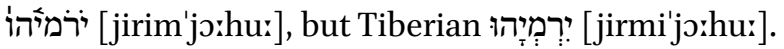

The weaker metrical structure of Babylonian, with less constraints against sequences of weak syllables, may reflect a less careful tradition of reading. The 
Tiberian tradition, which was the most prestigious tradition and the one that was most rigorously fixed, was evidently a more carefully read traditon and exhibits more constraints on weak syllables.

\section{References}

Alvestad, Silje, and Lutz Edzard. 2009. La-Ȟ̌sōb but La-Hăzōr?: Sonority, Optimality, and the Hebrew פ" פ" Forms. Abhandlungen für die Kunde des Morgenlandes, Bd. 66. Wiesbaden: Harrassowitz.

Blapp, Samuel. 2017. “The Non-Standard Tiberian Hebrew Language Tradition According to Bible Manuscripts from the Cairo Genizah." Ph.D. thesis, Cambridge: University of Cambridge.

DeCaen, Vincent. 2003. "Hebrew Sonority and Tiberian Contact Anaptyxis: The Case of Verbs Primæ Gutturalis." Journal of Semitic Studies 48 (1): 35-46.

Dotan, Aron. 1985. "Pathé Hațfin—a Study in the Evolution of the Tiberian Vocalization." In Avraham Even-Shoshan Volume, edited by Ben-Zion Luria, 157-165. Jerusalem: Kiryath Sepher (in Hebrew).

Eldar, Ilan. 1988. “The Treatise on the Shewa and 'Seder Ha-Simanim'-Two Parts of a Whole." In Studies in Hebrew and Arabic in Memory of Dov Eron, edited by Aron Dotan, 127-138. Te'uda 6. Tel-Aviv: Tel-Aviv University (in Hebrew).

Ewen, Colin J., and Harry van der Hulst. 2001. The Phonological Structure of Words. Cambridge: Cambridge University Press.

Hall, Nancy. 2011. "Vowel Epenthesis." In The Blackwell Companion to Phonology, edited by Marc van Oostendorp, Colin J. Ewen, Elizabeth Hume, and Keren Rice, 1576-1596. Malden, MA-Oxford: Wiley-Blackwell.

Halle, Morris, and Jean-Roger Vergnaud. 1987. An Essay on Stress. Current Studies in Linguistics 15. Cambridge, MA: MIT Press.

Hayes, Bruce. 1985. "Iambic and Trochaic Rhythm in Stress Rules." Proceedings of the Berkeley Linguistic Societ 11: 429-446.

Hayes, Bruce. 1995. Metrical Stress Theory: Principles and Case Studies. London: University of Chicago Press.

Heijmans, Shai. 2016. "Babylonian Tradition." In A Handbook of Biblical Hebrew, edited by W. Randall Garr and Steven E. Fassberg, 133-146. Winona Lake, IN: Eisenbrauns.

Hoberman, Robert. 1989. "Initial Consonant Clusters in Hebrew and Aramaic." Journal of Near Eastern Studies 48 (1): 25-29.

Itô, Junko. 1989. "A Prosodic Theory of Epenthesis." Natural Language and Linguistic Theory 7: 217-259.

Kager, René. 1993. "Alternatives to the Iambic-Trochaic Law." Natural Language \& Linguistic Theory 11: 381-432. 
Kager, René. 2007. “Feet and Metrical Stress." In The Cambridge Handbook of Phonology, edited by Paul de Lacy, 195-228. Cambridge: Cambridge University Press.

Khan, Geoffrey. 1987. "Vowel Length and Syllable Structure in the Tiberian Tradition of Biblical Hebrew." Journal of Semitic Studies 32 (1): 23-82.

Khan, Geoffrey. 1991. "The Syllabic Nature of Tiberian Hebrew Vocalization." In Semitic Studies in Honor of Wolf Leslau, edited by Alan S. Kaye, 850-865. Wiesbaden: Harrassowitz.

Khan, Geoffrey. 1992. "The Function of the Shewa Sign in Vocalized Judaeo-Arabic Texts from the Genizah." In Genizah Research after Ninety Years: The Case ofJudaeo-Arabic, edited by Joshua Blau and Stefan Reif, 105-111. University of Cambridge Oriental Publications 47. Cambridge: Cambridge University Press.

Khan, Geoffrey. 1994. "The Historical Background of the Vowel Șere in some Hebrew Verbal and Nominal Forms." Bulletin of the School of Oriental and African Studies 57 (1): 133-144.

Khan, Geoffrey. 1995. "The Pronunciation of the Reš in the Tiberian Tradition of Biblical Hebrew." Hebrew Union College Annual 66: 67-8o.

Khan, Geoffrey. 2010. "Vocalised Judaeo-Arabic Manuscripts in the Cairo Genizah." In "From a Sacred Source": Genizah Studies in Honour of Professor Stefan C. Reif, edited by Ben Outhwaite and Siam Bhayro, 201-218. Leiden-Boston: Brill.

Khan, Geoffrey. 2013a. A Short Introduction to the Tiberian Masoretic Bible and Its Reading Tradition. 2nd ed. Piscataway, NJ: Gorgias.

Khan, Geoffrey. 2013b. "Resh, Pre-Modern Hebrew." In Encyclopedia of Hebrew Language and Linguistics, edited by Geoffrey Khan, Shmuel Bolozky, Steven E. Fassberg, Gary A. Rendsburg, Aaron D. Rubin, Ora R. Schwarzwald, and Tamar Zewi, 3:384389. Leiden-Boston: Brill.

Khan, Geoffrey. 2013c. "Tiberian Reading Tradition." In Encyclopedia of Hebrew Language and Linguistics, edited by Geoffrey Khan, Shmuel Bolozky, Steven E. Fassberg, Aaron Rubin, Ora R. Schwarzwald, and Tamar Zewi, 3:769-778. Leiden-Boston: Brill.

Khan, Geoffrey. 2013d. “Vocalization, Babylonian.” In Encyclopedia of Hebrew Language and Linguistics, edited by Geoffrey Khan, Shmuel Bolozky, Steven E. Fassberg, Gary A. Rendsburg, Aaron D. Rubin, Ora R. Schwarzwald, and Tamar Zewi, 3:953-963. Leiden-Boston: Brill.

Khan, Geoffrey. 2013e. "Vowel Length: Biblical Hebrew." In Encyclopedia of Hebrew Language and Linguistics, edited by Shmuel Bolozky, Steven E. Fassberg, Aaron D. Rubin, and Ora R. Schwarzwald, 3:981-985. Leiden-Boston: Brill.

Khan, Geoffrey. 2020. The Tiberian Pronunciation Tradition of Biblical Hebrew. 2 volumes. Semitic Languages and Cultures 1. Cambridge: University of Cambridge \& Open Book Publishers.

Kiparsky, Paul. 2003. "Syllables and Moras in Arabic." In The Syllable in Optimality 
Theory, edited by Caroline Féry and Ruben Florentius Hendricus Eduardus van de Vijver, 147-182. Cambridge: Cambridge University Press.

Lambert, Mayer. 1891. Commentaire sur le Séfer Yesira, ou Livre de la Création. Paris: É. Bouillon.

Levy, Kurt. 1936. Zur Masoretischen Grammatik. Bonner Orientalistische Studien. Stuttgart: Kohlhammer.

Liberman, Mark, and Alan Prince. 1977. "On Stress and Linguistic Rhythm." Linguistic Inquiry 8: 249-233.

Nespor, Marina, and Irene Vogel. 2012. Prosodic Phonology. Walter de Gruyter.

Prince, Alan. 1983. "Relating to the Grid." Linguistic Inquiry 14: 19-100.

Prince, Alan. 199o. "Quantitative Consequences of Rhythmic Organization." In Parasession on the Syllable in Phonetics and Phonology, edited by Michael Ziolkowski, Manuela Noske, and Karen Deaton, 355-398. Chicago: Chicago Linguistic Society.

Sarauw, Christian Preben Emil. 1939. Über Akzent und Silbenbildung in den Älteren Semitischen Sprachen. Historisk-Filologiske Meddelelser, Det Kgl. Danske Videnskabernes Selskab 26, 8. København: Ejnar Munksgaard.

Selkirk, Elisabeth O. 1984. Phonology and Syntax: The Relation between Sound and Structure. Cambridge, MA: MIT Press.

Vennemann, Theo. 1988. Preference Laws for Syllable Structure and the Explanation of Sound Change. Berlin: Mouton de Gruyter.

Watson, Janet. 2007. "Syllabification Patterns in Arabic Dialects: Long Segments and Mora Sharing." Phonology 24: 335-356.

Yeivin, Israel. 1968. Aleppo Codex. Jerusalem: Magnes Press, Hebrew University (in Hebrew).

Yeivin, Israel. 1980. Introduction to the Tiberian Masorah. Masoretic Studies. Missoula: Scholars Press.

Yeivin, Israel. 1981. "The Gacyot and Their Function." Lěšonénu 46: 39-56 (in Hebrew).

Yeivin, Israel. 1985. The Hebrew Language Tradition as Reflected in the Babylonian Vocalization. Jerusalem: The Academy of the Hebrew Language (in Hebrew). 